\title{
Adaptation of the European Commission- recommended user testing method to patient medication information leaflets in Japan
}

This article was published in the following Dove Press journal:

Drug, Healthcare and Patient Safety

14 June 2017

Number of times this article has been viewed

\author{
Michiko Yamamoto' \\ Hirohisa Doi' \\ Ken Yamamoto ${ }^{2}$ \\ Kazuhiro Watanabe ${ }^{2}$ \\ Tsugumichi Sato ${ }^{3}$ \\ Machi Suka ${ }^{4}$ \\ Takeo Nakayama ${ }^{5}$ \\ Hiroki Sugimori ${ }^{6}$ \\ 'Department of Drug Informatics, \\ Center for Education \& Research \\ on Clinical Pharmacy, Showa \\ Pharmaceutical University, Tokyo, \\ Japan; ${ }^{2}$ Department of Pharmacy \\ Practice, Center for Education \& \\ Research on Clinical Pharmacy, Showa \\ Pharmaceutical University, Tokyo, \\ Japan; ${ }^{3}$ Faculty of Pharmaceutical \\ Sciences, Tokyo University of Science, \\ Chiba, Japan; ${ }^{4}$ Department of Public \\ Health and Environmental Medicine, \\ The Jikei University School of \\ Medicine, Tokyo, Japan; ${ }^{5}$ Department \\ of Health Informatics, Kyoto \\ University School of Public, Kyoto, \\ Japan; ${ }^{6}$ Department of Preventive \\ Medicine, Graduate School of Sports \\ and Health Sciences, Daito Bunka \\ University, Saitama, Japan
}

Correspondence: Michiko Yamamoto Department of Drug Informatics, Center for Education \& Research on Clinical Pharmacy, Showa Pharmaceutical University, 3-3165 Higashi-

Tamagawagakuen, Machidashi, Tokyo 194-8543, Japan

Tel $+8 \mid 4272$ I 15||

Fax +8I 427211588

Email m-yamamoto@ac.shoyaku.ac.jp
Background: The safe use of drugs relies on providing accurate drug information to patients In Japan, patient leaflets called Drug Guide for Patients are officially available; however, their utility has never been verified. This is the first attempt to improve Drug Guide for Patients via user testing in Japan.

Purpose: To test and improve communication of drug information to minimize risk for patients via user testing of the current and revised versions of Drug Guide for Patients, and to demonstrate that this method is effective for improving Drug Guide for Patients in Japan.

Method: We prepared current and revised versions of the Drug Guide for Patients and performed user testing via semi-structured interviews with consumers to compare these versions for two guides for Mercazole and Strattera. We evenly divided 54 participants into two groups with similar distributions of sex, age, and literacy level to test the differing versions of the Mercazole guide. Another group of 30 participants were divided evenly to test the versions of the Strattera guide. After completing user testing, the participants evaluated both guides in terms of amount of information, readability, usefulness of information, and layout and appearance. Participants were also asked for their opinions on the leaflets.

Results: Response rates were $100 \%$ for both Mercazole and Strattera. The revised versions of both Guides were superior or equal to the current versions in terms of accessibility and understandability. The revised version of the Mercazole guide showed better ratings for readability, usefulness of information, and layout $(p<0.01)$ than did the current version, while that for Strattera showed superior readability and layout $(p<0.01)$.

Conclusion: User testing was effective for evaluating the utility of Drug Guide for Patients. Additionally, the revised version had superior accessibility and understandability.

Keywords: user testing, drug information for patients, readability, risk management, risk communication, accessibility, understandability

\section{Plain language summary}

Providing patients with accurate drug information is essential to ensure that they use the drugs properly. In particular, persons involved in the preparation of patient leaflets for drugs must aim to ensure the drug usability. User testing is a useful method to assess whether patients could both access and understand the key messages in the leaflets. In Japan, Drug Guide for Patients (DGPs) are provided as official patient leaflets for prescription drugs.

We evaluated the current DGPs, as well as our revised version of the DGPs in Japanese, based on user testing recommended by the European Commission.

User testing was found to be effective for evaluating the usability of DGPs. Additionally, the revised version of the DGPs had superior accessibility and understandability than the current DGPs. This is the first Japanese study that sought to improve patient leaflets for drugs via user testing. 


\section{Background}

Providing patients with accurate drug information is essential for ensuring that patients use drugs properly. ${ }^{1-3}$ In particular, those involved in the preparation of patient leaflets for drugs must aim to ensure their usability—namely, designed to meet the needs of patients and support safe and appropriate use of medications - rather than mere compliance with the law.

In Japan, drug information leaflets for patients (Yakuzai-Joho-Teikyosho or Yakujo) are usually delivered to patients at the pharmacy for prescribed drugs ${ }^{4}$. These contain bare minimum information, including the drug name, dosage and administration, and effects and side effects. There are also medication instructions (Kusuri no Siori) ${ }^{5}$ available on the Internet; these are provided by the Risk/Benefit Assessment of Drugs-Analysis and Response Council, Japan, ${ }^{6}$ an association of pharmaceutical companies. These instructions summarize the drug information in one page, but often contain jargon regarding side effects, and thus require pharmacists' support. Notably, some pharmacies in Japan favor use of the Kusuri no Siori over the Yakujo. ${ }^{4}$ However, these two materials are insufficient for helping patients understand drugs well. This led the Ministry of Health, Labour and Welfare (MHLW) to design and implement, in 2005, the Drug Guide for Patients (DGPs).

The DGPs ${ }^{7}$ communicate accurate information about drugs; indeed, their content must comply with that of package inserts of the same drugs. However, while the latter are directed at healthcare professionals, the former are designed to be understandable for patients with at least a high school education level. DGPs are primarily used to help patients understand prescription drugs and to help with early detection of serious side effects. Currently, the pharmaceutical products targeted at DGPs are those with a warning section in their package inserts, those suggesting that healthcare professionals should explain the use of the drug to patients (usually found in the "precautions on use" section of the package insert), and those that contain information on proper use for patients in the package inserts. In April 2012, the MHLW newly established the Pharmaceutical Products Risk Management Plan for new drugs, which regulated the conditions of the creation of DGPs as a means of minimizing patient risk. ${ }^{8}$

In a previous study, we compared these drug guides with authorized patient leaflets for drugs in Japan, the European Union, and the United States to highlight the differences among them. ${ }^{9}$ DGPs were found to be similar to the Package Leaflets (PLs) regulated by the European Union (EU), which are normally delivered to patients in the form of package inserts. ${ }^{10,11}$ Furthermore, the concept of DGPs was found to be similar to the Medication Guides regulated by the US Food and Drug Administration, which were established as a requirement for being approved for a Risk Evaluation and Mitigation Strategy. ${ }^{12}$ However, DGPs are not disseminated as printed materials; they are only available on the web via the Pharmaceuticals and Medical Devices Agency website. ${ }^{13}$ DGPs do not appear to have spread well, and the actual situation of their use has not yet been determined. ${ }^{14}$

In a previous study, we conducted a questionnaire survey of the pharmacists in the community pharmacies and the hospitals in Mie and Yamagata prefectures to investigate their views for the actual circumstances of DGPs utilization and to understand the existing barriers associated with the use of DGPs as medication instructions for patients. We sent the questionnaires by mail to the facilities and obtained responses from 444 (33.9\%) of 1309 facilities and the number of the pharmacists in those facilities was 544 in total. ${ }^{14}$ Our results indicated that the terminology and expressions were often too complex, making the DGPs overly difficult to understand. Furthermore, most contained too large a volume of letters and text, making them difficult to read, and most were overly focused on side effects, which could potentially lead to poor drug adherence. These results indicated a need to review the current contents of DGPs to promote wider use.

In order to improve communication of important drug information, and thereby minimize risk for patients and consumers, we created revised DGPs for several drugs based on the results mentioned above, and examined whether these revised guides appropriately communicated risk. Specifically, we conducted a comparative assessment of current and revised guides via user testing. In Japan, user testing is not a mandatory practice. Furthermore, it has never been performed, to our knowledge, and no articles on its use have been published by Japanese research teams. User testing is the gold standard by which usability of medication information for patients is evaluated, and ensures that patients' views on the content and layout of the guides are considered, which can help patients make safer and more accurate decisions about their drugs. ${ }^{15}$ Thus, we planned to validate the DGPs via user testing.

\section{Method}

\section{Design}

User testing is a means of identifying problems with written documents such as leaflets for patients and generating suggestions for how these problems might be improved by directly 
targeting the users of such documents. To investigate whether patients could both access and understand the key messages of the DGPs and thereby safely use the drugs in question, we conducted face-to-face, semi-structured interviews using a questionnaire as suggested by the "Guideline on the readability of the labeling and package leaflet of medicinal products for human use" published by the European Commission in 2009, and followed the methodology this document proposes for user testing. ${ }^{16}$ The target outcome of this user testing method was that, when information within the DGPs is requested, it should be found by $90 \%$ of test participants, of whom $90 \%$ should show that they understand it. After the completion of user testing, all participants were asked to evaluate both DGPs.

\section{Participants}

Participants were recruited from the surrounding neighborhood or from among the acquaintances of previous participants through word-of-mouth or by handbill.

In total, we recruited 54 individuals for user testing for a drug guide for Mercazole (generic name: thiamazole) $5 \mathrm{mg}$ tablets and another 30 individuals for testing a drug guide for Strattera (generic name: atomoxetine) 5, 10, 25, and $40 \mathrm{mg}$. We evenly divided the 54 individuals in the first group into two groups with similar distributions of sex, age (10-79 years), and literacy level, to test the current and revised versions of the Mercazole drug guide. We further evenly divided the 30 individuals into two groups again considering age (20 to 69 years), sex, and literacy to test the current and revised versions of Strattera.

Before starting the user testing of Strattera, we administered a written document that explained the following: "please suppose that you became the parent of a child with attention deficit hyperactivity disorder (ADHD). Your child is a boy, and has a height of 155 centimeters and a weight of 50 kilograms". It should be noted that all members of the Strattera testing group had at least one child. We chose the age range for the Mercazole testing because it is a medicine that targets hyperthyroidism, and is widely used in Japan for individuals in their late teens to $70 \mathrm{~s}$.

We excluded all healthcare professionals such as medical doctors, pharmacists, nurses, clinical psychotherapists, and clinical staff. Table 1 shows the characteristics of the participants. We explained the purpose of the study to all participants and that participation was entirely voluntary, after which their written informed consent was obtained. The study was approved by the research ethics committee of the School of Healthcare, Showa Pharmaceutical University.

\section{Materials}

We performed a comparative assessment of the current and revised versions of two DGPs of Mercazole and Strattera. The current and revised version of Drug Guide for Patients for Mercazole in English are shown in Figures 1 and 2 (see Supplementary materials for Japanese version in Figures S1 and S2). The reason that we chose Mercazole is because it has a serious side effect called agranulocytosis, which occurred numerous times in Japan despite the attention given to patients using this drug by the government and pharmaceutical companies. It is highly important that patients themselves notice the symptoms such as fever, whole body weariness, and sore throat, early on. Furthermore, we chose Strattera because of the difficulty in treating patients with ADHD and the problem of non-adherence to such drugs. It is thus necessary for patients to fully understand the contents of the drug leaflets. The current and revised version of Drug Guide for Patients for Strattera in the English version are shown in Figures 3 and 4 (see Supplementary materials for Japanese version in Figures S3 and S4).

The current and revised versions of the Guides for Mercazole, updated in September 2013, ${ }^{17}$ and Strattera, updated in November $2013,{ }^{18}$ had no tables of contents or subindexes. They were in black and white, and listed only serious side effects rather than all side effects. Furthermore, they contained no information on the frequency of serious side effects.

In contrast, the revised versions of the DGPs contained the following revisions:

1. The Guide is structured with a table of contents with various subindexes, and accompanying page numbers (Box 1).

2. The following subindex items were newly created:

- Clinical tests before taking this drug

- Clinical tests while taking this drug

- Other medications and this drug

- Use with food, drink, and alcohol

Information on the following topics related to taking the medication was included in the document as subindex items in the table of contents:

- What is it used for?

- Old age

- Pregnancy or breast-feeding

- Children

- Driving and using machines

3. The description of adverse reactions was revised as follows:

- Technical terms and expressions were modified to plain language. 
Drug Guide for Patients

Revised in September 2013

\section{Mercazole Tablet 5mg}

\section{【What is this drug?】}

Brand name : Mercazole Tablet 5mg

Generic name: Thiamazole

Content : Thiamazole 5mg in one tablet

\section{About the Drug Guides for Patients}

"Drug Guides for Patients" are prepared for patients and their family members to understand the prescription drug properly and to help detect serious adverse reactions in an early stage.

Therefore, this leaflet explains the content of the package insert in an easier manner than had been originally prepared for healthcare professionals, so that a user understands what he/she should know when using this drug.

If you think it is a serious adverse reaction of the drug use, immediately consult your physician or pharmacist.

If there is anything that you do not understand, there is a contact phone number at the end of this leaflet. For further information, please visit "Website providing pharmaceutical and medical device information," http://www.info.pmda.go.jp/ for the package leaflet information for healthcare professionals.

【What is the effect of this drug?】

- This drug belongs to a group of treatment drugs called "Antithyroid Drug."

- This drug acts on the thyroid gland by inhibiting the function of the enzyme needed for synthesizing thyroid hormone, resulting in suppressing an excessive secretion of thyroid hormone.

- It is prescribed for the following disease.

\section{Hyperthyroidism}

- It takes time for this drug to become effective.

- It is important to take this drug as directed. Do not stop this drug even if you feel better by your own decision nor increase the dose when you feel that the drug is not working.

【What are the things you should confirm before taking this drug?】

There are reports of death from serious agranulocytosis within two months of taking this drug.

Principally a blood test is conducted every two weeks for two months from the start of this drug. Subsequently a regular blood test is conducted. Please visit your physician for the test. When you stop taking this drug, but start again, the same blood test must be conducted.

$\bigcirc$ When you become agranulocytosis, you tend to get infection easily with occasional symptoms of "attack of fever," "sore throat" and "a sense of fatigue of the entire body," which are similar to a cold or tonsillitis. If you notice such symptoms, do not leave untreated such conditions with your own judgment considering that you have just caught a cold, but immediately consult your physician.

The following people cannot use this drug

- A person who has experienced hypersensitive reaction to Mercazole in the past.

Following people must use this drug in a careful manner. Please tell your physician or pharmacist about it before using this drug.

- A person having liver disorder

- A person having leucopenia or other blood disorder

Figure I (Continued) 
You must be careful when using this drug in combination with other drugs. If you are currently taking other drugs or initiating them, do not fail to inform your physician or pharmacist.

【How do you use this drug?】

- Dosage and frequency

Your physician will decide the dosage according to your symptoms.

Normally the dosage and frequency of taking this drug are the following.

\begin{tabular}{|c|c|c|c|c|c|}
\hline & \multicolumn{2}{|c|}{ Starting dosage } & \multicolumn{2}{|c|}{ Maintenance dosage } \\
\hline & & Dose & Frequency & Dose & Frequency \\
\hline \multirow[t]{2}{*}{ Adult } & Normal & 6 tablets a day & Take 3 or 4 & \multirow{5}{*}{$\begin{array}{c}1-2 \text { tablets } \\
\text { a day }\end{array}$} & \multirow{5}{*}{$\begin{array}{l}\text { Take } 1-2 \\
\text { times a day } \\
\text { as one day } \\
\text { dose }\end{array}$} \\
\hline & $\begin{array}{l}\text { Serious } \\
\text { case }\end{array}$ & $\begin{array}{l}8-12 \text { tablets a } \\
\text { day }\end{array}$ & $\begin{array}{l}\text { times a day as } \\
\text { one day dose }\end{array}$ & & \\
\hline \multirow[t]{2}{*}{ Child } & $\begin{array}{l}5 \text { yrs to less } \\
\text { than } 10 \text { yrs }\end{array}$ & $\begin{array}{l}2-4 \text { tablets a } \\
\text { day }\end{array}$ & \multirow{2}{*}{$\begin{array}{l}\text { Take } 2 \text { or } 4 \\
\text { times a day as } \\
\text { one day dose }\end{array}$} & & \\
\hline & $\begin{array}{l}10 \text { yrs to } \\
\text { less than } 15 \\
\text { yrs }\end{array}$ & $\begin{array}{l}\text { 4-6 tablets a } \\
\text { day }\end{array}$ & & & \\
\hline \multicolumn{2}{|c|}{ Pregnant woman } & $\begin{array}{l}3-6 \text { tablets a } \\
\text { day }\end{array}$ & $\begin{array}{l}\text { Take } 3 \text { or } 4 \\
\text { times a day as } \\
\text { one day dose }\end{array}$ & & \\
\hline
\end{tabular}

When almost all the symptoms disappear with the starting dosage, the drug dosage should be decreased every 1 to 4 weeks and then kept as maintenance dosage.

- How do you take this drug?

- This drug is taken with a glass of room temperature water.

- If you forget to take this drug:

Never take two doses at once.

When you notice you have skipped one dose, take one dose immediately. If the next taking time is close, skip it and take the next dose at the next taking time.

- If you take too many doses (overdose):

There is a possibility of symptoms such as goiter (swelling of thyroid) or hypothyroidism (body weariness, slow activity or speech, swelling and/or feeling chilly). If several symptoms appear at the same time, please consult your physician or pharmacist immediately.

【What do you have to be careful about when taking this drug?】

- Principally a blood test is conducted every two weeks for two months from the start of this drug. Subsequently a regular blood test is conducted. Please observe the visit to your physician for the test.

- If you are pregnant, possibly pregnant, or breast-feeding, please consult your physician.

- Thyroid function test is conducted every two weeks during the pregnancy.

- If you see another physician or purchase other drugs at the pharmacy, please tell the physician or the pharmacist that you are taking this drug.

\section{What are the adverse reactions?}

We list out serious adverse reactions and their major subjective symptoms below that need to be paid special attention to. It is common that a few subjective symptoms of adverse reactions appear at the same time described in each of the following serious adverse reactions. If this happens, immediately consult your physician or pharmacist.

\begin{tabular}{|c|l|}
\hline $\begin{array}{c}\text { Serious adverse } \\
\text { reactions }\end{array}$ & \multicolumn{1}{c|}{ Major subjective symptoms } \\
\hline Pancytopenia & $\begin{array}{l}\text { Dizziness, palpitation, ear ringing, nose bleeding, bleeding } \\
\text { tendency, bleeding of gums, bruising, and breathlessness }\end{array}$ \\
\hline
\end{tabular}

Figure I (Continued) 


\begin{tabular}{|c|c|}
\hline Aplastic anemia & $\begin{array}{l}\text { Palpitation and breathlessness when walking up the stairs } \\
\text { or slope, nose bleeding, palpitation, breathlessness, bruising } \\
\text { dizziness, bleeding of gums, and bleeding tendency }\end{array}$ \\
\hline Agranulocytosis & Fever attack, sore throat, and body weariness \\
\hline Leukopenia & Fever attack, sore throat, and body weariness \\
\hline Hypoprothrombinemia & $\begin{array}{l}\text { Bleeding tendency, bruising, not easy to stop } \\
\text { bleeding, bleeding of gums, and nose bleeding }\end{array}$ \\
\hline Deficiency of factor VII & Not easy to stop bleeding, bleeding tendency, and bruising \\
\hline Thrombocytopenia & $\begin{array}{l}\text { Bleeding of gums, internal bleeding, nose bleeding, not easy } \\
\text { to stop bleeding, and bruising }\end{array}$ \\
\hline $\begin{array}{l}\text { Thrombocytopenic } \\
\text { purpura }\end{array}$ & Bleeding of gums, internal bleeding, and nose bleeding \\
\hline Liver disorder & $\begin{array}{l}\text { Skin and the white of eyes become yellow, urine color } \\
\text { becomes dark, vomiting, nausea, lack of appetite, and } \\
\text { itchiness, body weariness }\end{array}$ \\
\hline Jaundice & $\begin{array}{l}\text { Skin and the white of eyes become yellow, and urine color } \\
\text { becomes brown }\end{array}$ \\
\hline Multiple arthritis & Pain in joints, and swelling in joints \\
\hline SLE-like symptom & $\begin{array}{l}\text { Red butterfly-shape speckle in the face, fever attack, muscle } \\
\text { pain, pain the in joints, swelling of lymph node, body } \\
\text { weariness, and pain in the upper stomach }\end{array}$ \\
\hline $\begin{array}{l}\text { Insulin autoimmune } \\
\text { syndrome }\end{array}$ & $\begin{array}{l}\text { Cold sweats, hunger, palpitation, headache, shivering of } \\
\text { limbs, wobbling, dizziness, and sense of exhaustion }\end{array}$ \\
\hline Interstitial pneumonia & $\begin{array}{l}\text { Difficulty in breathing, breathlessness, fever attack, and dry } \\
\text { cough }\end{array}$ \\
\hline $\begin{array}{l}\text { ANCA-Associated } \\
\text { vasculitis syndrome }\end{array}$ & $\begin{array}{l}\text { Fever attack, pain in the joints, difficulty in breathing, rash, } \\
\text { internal bleeding, headache, numbness and/or paralysis, } \\
\text { bloody urine, and anemia }\end{array}$ \\
\hline Rhabdomyolysis & $\begin{array}{l}\text { Stiffness in limbs, numbness in limbs, sense of exhaustion, } \\
\text { muscle pain, and reddish brown urine }\end{array}$ \\
\hline
\end{tabular}

The above subjective symptoms can be categorized by the body locations where adverse reactions may appear as follows. If you notice such symptoms, please refer to the chart of serious adverse reactions.

\begin{tabular}{|l|l|}
\hline \multicolumn{1}{|c|}{ Body Location } & \multicolumn{1}{c|}{ Subjective symptoms } \\
\hline Entire body & $\begin{array}{l}\text { Fever attack, pain in the joints, swelling in joints, swelling in } \\
\text { lymph nodes, body weariness, cold sweats, wobbling, and sense } \\
\text { of exhaustion }\end{array}$ \\
\hline Head area & Dizziness, and headache \\
\hline Face & Nose bleeding, and red butterfly-shape speckle in the face \\
\hline Eyes & The white of eyes become yellow \\
\hline Ears & Ear ringing \\
\hline Mouth \& throat & Bleeding in gums, sore throat, vomiting, nausea, and dry cough \\
\hline Chest area & $\begin{array}{l}\text { Palpitation, breathlessness, palpitation and breathlessness } \\
\text { when walking up the stairs or slope, nausea, and difficulty in } \\
\text { breathing }\end{array}$ \\
\hline Stomach area & Nausea, lack of appetite, pain in the upper stomach, and hunger \\
\hline Hands and legs & $\begin{array}{l}\text { Pain in the joints, swelling in joints, shaking of limbs, stiffness } \\
\text { of limbs, and numbness of limbs }\end{array}$ \\
\hline Skin & $\begin{array}{l}\text { Bruising, internal bleeding, skin becomes yellow, itchiness, } \\
\text { and rash }\end{array}$ \\
\hline Muscle & $\begin{array}{l}\text { Muscle pain } \\
\text { Urine color becomes dark, urine color becomes brown, bloody } \\
\text { urine, and reddish brown urine }\end{array}$ \\
\hline Urine & $\begin{array}{l}\text { Bleeding tendency, not easy to stop bleeding, numbness } \\
\text { and/or paralysis, and anemia }\end{array}$ \\
\hline Others &
\end{tabular}

【What is the shape of this drug?】

\begin{tabular}{|c|c|}
\hline Shape & Round tablet \\
& \\
\hline Diameter & $8.3 \mathrm{~mm}$ \\
\hline Thickness & $4.6 \mathrm{~mm}$ \\
\hline Weight & $250 \mathrm{mg}$ \\
\hline Color & White \\
\hline ID code & Mercazole 5 \\
\hline
\end{tabular}

Figure I (Continued) 
【What are the ingredients of this drug?】

\begin{tabular}{|l|l|}
\hline Active ingredient & Thiamazole \\
\hline Excipients & $\begin{array}{l}\text { Lactose hydrate, corn starch, talc, hypromellose, refined sugar, } \\
\text { gelatin, oxidized titanium, precipitated calcium carbonate, } \\
\text { magnesium stearate, gum Arabic powder, carnauba wax, } \\
\text { stearic acid, white shellac, polyoxyethylene (160), } \\
\text { polyoxypropylene (30), and glycol }\end{array}$ \\
\hline
\end{tabular}

\section{【Other information】}

- How do you store this drug?

- Please store this drug at room temperature $\left(1 \sim 30^{\circ} \mathrm{C}\right)$ and avoid sunlight and humidity.

- Please keep out of reach of children.

- What do you do with the unused drugs?

- Never give them to other people.

- If you have remaining drugs in hand, please consult your pharmacy or medical institution.

【Who do you ask about this drug?】

- For further questions such as symptoms, usage and adverse reactions, please ask your physician or your pharmacist.

- For general information, please contact the following manufacturer.

Marketing authorization holder and manufacturer:

Chugai Pharmaceutical Co., Ltd.

(http://www.chugai-pharm.co.jp)

Drug information center

Telephone: 0120-189706

Figure I Current version of the Mercazole Drug Guide for Patients in English.

- The most serious adverse reactions were listed prominently with clear instructions to patients on what action to take such as "stop taking Mercazole/ Strattera and call your doctor immediately".

All other side effects were listed by frequency along with their subjective symptoms. Frequencies were defined as follows: Very common; may affect more than 1 in 10 people. Common; may affect up to 1 in 10 people. Uncommon; may affect up to 1 in 100 people. Rare; may affect up to 1 in 1,000 people. Very rare; may affect up to 1 in 10,000 people. Not known; frequency cannot be estimated from the available data.

4. The front page contained a color photograph of the dosage form.

5. Important sections were printed in red boldface font.

6. The explanation of DGPs was moved to the end.

\section{Outcome}

The primary endpoint of the study was the ability of participants to access and understand key information in the Drug Guide for Patients.
We chose the questionnaire items for the user testing of the Guides based on the European Commission Guidelines, ${ }^{10}$ which recommends taking the views of patients into account when developing PLs. Similar items are also published by the Medicines and Healthcare Products Regulatory Agency in the UK. ${ }^{19}$ These guidelines recommend that all questionnaire items comprise the following:

- Adequately cover any critical safety issues with the medicine.

- Be kept to a minimum; usually $12-15$ will be enough, though more may be required in special cases.

- Cover a balance of general and specific issues. A general issue might be what to do if a dose is missed, while a specific issue might relate to a side effect that occurs particularly with that medicine.

- Be phrased differently from the text of the leaflet to avoid "copycat" answers, based merely on identifying groups of words.

- Appear in a random order.

The questionnaire items for assessing the drug guides for Mercazole and Strattera were developed with reference 


\section{Drug Guide for Patients (Plan)}

Date of $1^{\text {st }}$ edition :

Date of the most recent revision :

\section{Mercazole Tablet 5mg}

\section{Generic name: Thiamazole}

\begin{tabular}{|l|l|}
\hline Brand name & Mercazole tablet 5mg \\
\hline Formulation & White sugar-coated tablet \\
\hline Shape & \\
& Diameter: $8.3 \mathrm{~mm}$ Thickness: $4.6 \mathrm{~mm} \quad$ Weight: $250 \mathrm{mg}$ \\
\hline ID Code & Mercazole 5 \\
\hline
\end{tabular}

\section{Contents}

1. What is this drug? $\cdots \cdots \cdot \cdots$ p2

-What is it used for?

- What is its effect?

2. What is the most important thing about this drug? .......... p2

3. What you need to know before taking this drug................ p2

- Do not take this drug, Precautions concerning use

- Clinical test before you take this drug

4. What you need to pay attention to when taking this drug ........ p

- Other medications and this drug

- Clinical tests while taking this drug

- Old age
- Pregnancy or breast-feeding

- Children

- Driving and using machines

- Use with food, drink and alcohol

- Information on inactive ingredients

5. How to use this drug . . . . p

- Dosage and administration

- If you forget to take this drug

- If you take too many doses (overdose)

6. Adverse reactions ......p

7. Others …..... p

- How to store this drug

- Active ingredients

- Marketing authorization holder and manufacturer

\section{What is this drug?}

\section{What is it used for?}

Mercazole is a drug used for treating hyperthyroidism (eg: graves disease). Graves disease is one of the auto-immune diseases of excessive production of thyroid hormone caused by antibodies to stimulate thyroid gland. Thyroid hormone promotes the metabolism of the body, but if too much is produced it many body organs such as heart and liver. It also causes fast pulse and hyperthyroidism. Additionally it will decrease the calcium of bones, resulting in osteoporosis.

\section{What is its effect?}

- This drug acts on the thyroid gland and inhibits the function of an enzyme that is necessary for the synthesis of thyroid hormone and as a result suppresses the excessive secretion of thyroid hormone.

- It takes 2 to 4 weeks before it becomes effective depending on the individual

- Please do not stop using it or increase the dose using your own judgment of getting better or the drug not working.

\section{What is the most important thing about this drug?}

Please use this drug after listening to your physician and/or pharmacist and fully understanding the following.

- There may be a severe case of agranulocytosis (fever attack, sore throat and weariness of the entire body) mainly within 2 months after starting this drug. These symptoms may increase. Therefore, if you notice such a symptom, please do not leave it as it is a cold but immediately consult your physician.

Figure 2 (Continued) 
- When you start taking this drug, a blood test is conducted. Principally this test is conducted every 2 weeks for the first 2 months and subsequent regular blood tests follow. Please visit your physicians for such tests. When you stop taking this drug, but start again, the same blood test must be conducted.

- If you stop taking this drug with your own judgment except when you notice the adverse reactions of this drug, the symptoms may reappear or adverse reactions may happen when you start taking this drug again. Please follow the instructions of your physician.

\section{Things to be warned before taking this drug.}

The following people must tell (consult with) your physician or pharmacist before using this drug. QFollowing people should not use this drug.

- A person who has experienced hypersensitive reaction the ingredients contained in Mercazole tablet in the past.

Following people must pay special attention when using this drug.

- A person having liver disease.

- A person suffering from leucopenia or other blood disorders.

There are certain drugs that require special attention when using in combination with this drug. If you are currently taking other drugs or going to newly use other drugs, please never fail to consult with your physician or pharmacist.

Clinical test before taking this drug.

There is no test needed before using this drug.

4. What you need to pay attention to when taking this drug.

$\bigcirc$ Other medication and this drug.

Attention is needed if you are currently taking the following drug or intend to start taking it.

Please never fail to consult your physician or pharmacist. It is necessary to be careful using these drugs together.

- Potassium Warfarin - a drug to treat thrombosis;

- Digoxin, etc. (Digitalis preparation) - a drug to treat heart failure; There is a case that the efficacy of digitalis preparation may be increased or decreased.

\section{Clinical tests while taking this drug}

Principally a blood test is conducted every 2 weeks for 2 months after you start taking this drug. Subsequent regular blood tests must be conducted. Please visit your physician for this test when you stop using it, but start again, the same blood test must be conducted.

$\bigcirc$ Old age

There is no particular information.

Pregnancy or breast-feeding

- If you are pregnant, have a possibility of being pregnant or are breast-feeding your child, please consult your physician.

- This drug may influence breast milk, so please avoid breast-feeding.

- Thyroid function test is conducted every two weeks during the pregnancy.

$\bigcirc$ Children

There is no particular information.

$\bigcirc$ Driving and using machines There is no particular information.

Use with food or beverage There is no particular information.

$O$ Information on inactive ingredients There is no particular information.

\section{How to use this drug}

Dosage and administration

- Your physician will prescribe the dosage of this drug according to your symptoms. Please observe the dosage instruction of this drug given by your physician.

Figure 2 (Continued) 
Starting dose is dosage from the start of this drug until almost all the symptoms disappear.

Maintenance dose is the dosage when almost all the symptoms disappear. When the symptoms disappear with the starting dose, the physician will gradually decrease the dosage every 1 to 4 weeks and decide the maintenance dose.

\section{Adult 【15 years or older】}

\begin{tabular}{|l|l|l|c|}
\hline \multicolumn{2}{|c|}{ Starting dose } & Maintenance dose \\
\hline Frequency & $3-4$ times a day & $1-2$ times a day \\
\hline \multirow{2}{*}{ One-day dosage } & Normal & 6 tablets a day & $1-2$ times a day \\
\cline { 2 - 3 } & Severe & $8-12$ tablets a day & \\
\hline
\end{tabular}

Child【14 years or younger 】

\begin{tabular}{|l|l|l|c|}
\hline \multicolumn{2}{|c|}{ Starting dose } & Maintenance dose \\
\hline Frequency & & $2-4$ times a day & $1-2$ times a day \\
\hline One-day dosage & $2-4$ tablets a day & $1-2$ times a day \\
& $\begin{array}{l}10 \text { yrs yrs - less } \\
\text { than } 15 \text { yrs }\end{array}$ & $4-6$ tablets aday & \\
\cline { 2 - 3 } & & \\
\hline
\end{tabular}

\section{Pregnant woman}

\begin{tabular}{|l|l|l|}
\hline \multicolumn{2}{|c|}{ Starting dose } & \multicolumn{1}{c|}{ Maintenance dose } \\
\hline Frequency & $3-4$ times a day & $1-2$ times a day \\
\hline One-day dosage & $3-6$ tablets a day & $1-2$ tablets a day \\
\hline
\end{tabular}

\section{If you forget to take this drug}

- When you notice skipping a dose, take one dose immediately. Never take two doses at one time.

- However, if the next taking time is close, skip it and take the next dose at the next taking time.

\section{$\bigcirc$ If you take too many doses (overdose)}

- Immediately contact your physician or nearby hospital and tell them how many tablets you have taken.

- Frequently reported overdose symptoms are goiter (swelling of thyroid) or hypothyroidism (body weariness, slow activity or speech, swelling or feeling chilly). When such symptoms appear, immediately contact your physician or pharmacist.

\section{Adverse reactions}

Side effects may occur, but they do not necessarily occur in everybody. However when adverse reactions happen, multiple symptoms may appear at the same time. When the symptoms occur, immediately consult your physician. Additionally if adverse reactions not described here occur, please consult your physician or pharmacist.

oSerious side effects (Frequency of occurrence: not known.)

$\checkmark$ When the following symptoms similar to a cold occur, stop taking the drug and immediately contact your physician or the hospital.

- Fever attack

- Sore throat

- Weariness of the entire body

\section{$\checkmark$ When the following symptoms occur, stop taking the drug and immediately contact your} physician or the hospital.

- Bleeding in gums, nose bleeding, getting bruises, and not easy to stop bleeding

- Palpitation and vertigo

- The white of your eyes or skin become yellow

- Urine becomes brown and/or bloody urine

- Red butterfly-shape speckle on the face

- Pain in the joints

- Swelling around eyes and mouth

Other side effects (Frequency of occurrence : not known)

If the following adverse reactions occur, please consult your physician or pharmacist.

Rash, darkening or erythema of skin, hair loss

Nausea, diarrhea, lack of appetite

Headache, dizziness

Figure 2 (Continued) 
Muscle pain, muscle spasm, numbness of the limbs

Taste abnormality

7. Others

How to store this drug

- Store the drug in a container with a lid at the room temperature $\left(1 \sim 30^{\circ} \mathrm{C}\right)$ avoiding direct sunlight and humidity.

- Keep this drug out of reach of children. Never give this drug to other people.

$\bigcirc$ Active ingredients and excipients

Active ingredients: Thiamazole

Excipients : Lactose hydrate, corn starch, talc, hypromellose, refined sugar, gelatin, oxidized titanium, precipitated calcium carbonate, magnesium stearate, gum Arabic powder, carnauba wax, stearic acid, white shellac, polyoxyethylene (160), polyoxypropylene (30), glycol

Marketing authorization holder and manufacturer

Marketing authorization holder and manufacturer:

Chugai Pharmaceutical Co., Ltd. (http://www.chugai-pharm.co.jp)

Drug information center: Telephone: 0120-189706

About the Drug Guides for Patients
"Drug Guides for Patients" are prepared for patients and their family members to
understand the prescription drug properly and to help detect serious adverse reactions in an
early stage.
Therefore, this leaflet explains the content of the package insert in an easier manner than
had been originally prepared for healthcare professionals, so that a user understands what
he/she should know when using this drug.
If you think it is a serious adverse reaction of the drug use, immediately consult your
physician or pharmacist.
If there is anything that you do not understand, there is a contact phone number at the
end of this leaflet. For further information, please visit "Website providing pharmaceutical
and medical device information," http://www.info.pmda.go.jp/ for the package leaflet
information for healthcare professionals.

Figure 2 Revised version of the Mercazole Drug Guide for Patients in English.

to these guidelines; the specific items are described in Box 2 and 3, respectively. Questions 8 and 12 were asked only for the revised version of the Strattera guide, because the answers to these questions were not present in the current Strattera guide. The key points assessed by the items were selected by three co-authors, all of whom were pharmacists. These key points reflected safe use of the drug (i.e., minimized risk of adverse reactions), including serious side effects, warnings on use, and so on.

\section{Procedure and outcome measures}

User testing questionnaires were administered following four pilot interviews. Interviewers told participants that they would be asked to imagine they needed to begin taking a medicine, and therefore should read a leaflet such as the drug guide about that medicine and then answer questions about it. The interviewers received a training session, which was provided to them in order to standardize the levels of their observational and listening skills before the user test.
First, participants were left alone for $\sim 3$ minutes to read the leaflet. Subsequently, the interviewer began asking the user testing questions. After the interviewer asked each question, each participant was allowed to open the leaflet and begin searching for the answer. The interviewer checked whether participants could find the correct answer and recorded the time that it took for them to find it. Answers were only accepted as "found" when it was evident that the participant was responding with reference to the correct place in the leaflet within two minutes. Interviewers also asked participants to rephrase answers to confirm their understanding of the questions. The interviewers made field notes on relevant actions and comments made by participants throughout the testing.

Secondly, after the interviewers had finished with the user testing questions, participants evaluated the drug guides on a 4-point scale (4: highly appropriate, 3: appropriate, 2 : inappropriate, and 1: highly inappropriate) in terms of amount of information, readability, usefulness of information, and layout and appearance (including indexes, blank space, and font size). Their responses were then compared using $t$-tests 
Drug Guide for Patients (Plan)

November 2013 Edition

\section{Strattera Capsules $\mathbf{5 m g}$ \\ Strattera Capsules 10mg \\ Strattera Capsules 25mg \\ Strattera Capsules $40 \mathrm{mg}$}

【What is this drug? 】

\begin{tabular}{|l|l|l|l|l|}
\hline Brand name & \multicolumn{1}{|c|}{$\begin{array}{c}\text { Strattera } \\
\text { Capsule 5mg }\end{array}$} & $\begin{array}{c}\text { Strattera } \\
\text { Capsule 10mg }\end{array}$ & $\begin{array}{c}\text { Strattera } \\
\text { Capsule 25mg }\end{array}$ & $\begin{array}{c}\text { Strattera } \\
\text { Capsule 40mg }\end{array}$ \\
\hline $\begin{array}{l}\text { Generic } \\
\text { name }\end{array}$ & \multicolumn{4}{|c|}{ Atomoxetine Hydrochloride } \\
\hline $\begin{array}{l}\text { Content } \\
\text { (per capsule) }\end{array}$ & $\begin{array}{l}\text { Atomoxetine } \\
\text { Hydrochloride }\end{array}$ & $\begin{array}{l}\text { Atomoxetine } \\
\text { Hydrochloride }\end{array}$ & $\begin{array}{l}\text { Atomoxetine } \\
\text { Hydrochloride }\end{array}$ & $\begin{array}{l}\text { Atomoxetine } \\
\text { Hydrochloride }\end{array}$ \\
& $\begin{array}{l}5.71 \mathrm{mg}(5 \mathrm{mg} \text { as } \\
\text { Atomoxetine) }\end{array}$ & $\begin{array}{l}\text { 11.43mg(10mg } \\
\text { as Atomoxetine) }\end{array}$ & $\begin{array}{l}\text { 28.57mg(25mg } \\
\text { as Atomoxetine) }\end{array}$ & $\begin{array}{l}\text { 45.71mg(40mg } \\
\text { as Atomoxetine) }\end{array}$ \\
\hline
\end{tabular}

\section{About the Drug Guides for Patients}

"Drug Guides for Patients" are prepared for patients and their family members to understand the prescription drug properly and to help detect serious adverse reactions in an early stage. Therefore, this leaflet explains the content of the package insert in an easier manner than had been originally prepared for healthcare professionals, so that a user understands what he/she should know when using this drug.

If you think it is a serious adverse reaction of the drug use, immediately consult your physician or pharmacist.

If there is anything that you do not understand, there is a contact phone number at the end of this leaflet. For further information, please visit "Website providing pharmaceutical and medical device information," http://www.info.pmda.go.jp/ for the package leaflet information for healthcare professionals.

【What is the effect of this drug?】

- This drug belongs to a group of treatment drug called "Attention Deficit/Hyper Activity Disorder (AD/HD).”

- This drug improves the symptoms of Attention Deficit/Hyper Activity Disorder (AD/HD) by adjusting the function of neurotransmitter substances in the brain.

- It is prescribed for the following patients.

\section{Attention Deficit/Hyper Activity Disorder (AD/HD)}

- Efficacy and safety are not confirmed for children of less than 6 years of age.

- Stopping or decreasing the dose of this drug by your own judgment of disease recovery may exacerbate the disease. It is important to keep taking this drug as instructed by your physician.

\section{【What are the things you should confirm before taking this drug?】}

$\bigcirc$ The following people should not take this drug:

- Those who have had an allergy reaction to the ingredients contained in the Strattera Capsule in the past.

- Those who are taking monoamine oxidase (MAO) inhibitors or who are within two weeks after stopping taking it.

- Those having serious disorder in the cardiovascular system.

- Those suffering from pheochromocytoma or suffered from pheochromocytoma in the past.

- Those having angle-closure glaucoma (acute eye pain, headache, nausea, blurred vision).

The following people should take special care when taking this drug. Please tell your physician or pharmacist before using this drug:

- Those having liver disorders.

- Those having kidney disorders

- Those having convulsive seizure or have had convulsive seizure in the past.

Figure 3 (Continued) 
- Those having heart disorder or have had heart disorder in the past.

- Those having congenital long QT interval syndrome or their relative having QT interval syndrome.

- Those suffering from hypertension or were hypertensive in the past.

- Those having cerebrovascular disorder or have had one in the past.

- Those having had orthostatic hypotension in the past.

- Those having mental problems such as psychotic disorder or bipolar disorder.

- Those having urinary disturbance.

There are some drugs that cannot be taken [monoamine oxidase (MAO) inhibitors, selegiline hydrochloride (FP)] or need special care in combination use. If you are taking some other drugs or going to take a new drug, please do not fail to consult your physician or pharmacist.

Blood pressure and heart rate (pulse rate) must be taken before using this drug to observe the influence to the cardiovascular system.

EKG examination should be conducted in case the patient or his/her family member has cardiac disturbances

\section{【How do you use this drug?】}

\section{- Dosage and frequency}

Normally the dosage and frequency of taking this drug are the following. Your physician will decide the dosage according to your symptoms.

- Special care must be taken to decide the dosage especially for those having liver damage.

[Under 18 years of age]

\begin{tabular}{|c|c|c|c|}
\hline Brand name & \multicolumn{3}{|c|}{ Strattera capsule $5 \mathrm{mg}, 10 \mathrm{mg}, 25 \mathrm{mg}, 40 \mathrm{mg}$} \\
\hline Frequency & \multicolumn{3}{|c|}{ Twice a day } \\
\hline \multirow[t]{2}{*}{$\begin{array}{l}\text { Total dosage for } \\
\text { one day }\end{array}$} & $\begin{array}{l}\text { Starting } \\
\text { dosage }\end{array}$ & Then after & Maintenance dosage \\
\hline & $\begin{array}{l}0.5 \mathrm{mg} \text { per } 1 \mathrm{~kg} \\
\text { of body weight }\end{array}$ & $\begin{array}{l}0.8 \mathrm{mg} \text { per } 1 \mathrm{~kg} \text { of body } \\
\text { weight, then increase to } \\
1.2 \mathrm{mg} \text { per } 1 \mathrm{~kg}\end{array}$ & $\begin{array}{l}* 1.2 \mathrm{mg} \text { to } 1.8 \mathrm{mg} \text { per } 1 \mathrm{~kg} \text { of body weight } \\
{ }^{*} \text { For the total dosage per day, the smaller } \\
\text { amount of } 120 \mathrm{mg} \text { or } 1.8 \mathrm{mg} \text { per } 1 \mathrm{~kg}\end{array}$ \\
\hline
\end{tabular}

* The dosage of this drug must be increased gradually using 1 week or more.

[18 years of age or more]

\begin{tabular}{|l|c|c|c|}
\hline Brand name & \multicolumn{3}{|c|}{ Strattera capsule $5 \mathrm{mg}, 10 \mathrm{mg}, 25 \mathrm{mg}, 40 \mathrm{mg}$} \\
\hline Frequency & \multicolumn{2}{|c|}{ Once or twice a day } \\
\hline \multirow{2}{*}{$\begin{array}{l}\text { Total dosage for } \\
\text { one day }\end{array}$} & $\begin{array}{c}\text { Starting } \\
\text { dosage }\end{array}$ & Then after & Maintenance dosage \\
\cline { 2 - 4 } & $40 \mathrm{mg}$ & Increase up to $80 \mathrm{mg}$ & $80 \mathrm{mg} \sim 120 \mathrm{mg}$ \\
\hline
\end{tabular}

* The dosage of this drug must be increased gradually over 1 week or more. The dosage increase after that should be done gradually over 2 weeks or more.

\section{- How do you take this drug?}

- This drug is taken with a glass of cold water or lukewarm water.

- Do not open the capsule, but take the drug as it is. The ingredients of the capsule are irritating to the eyes. If they are exposed to the eyes, immediately wash with water and consult your physician. If you touch them with your hands, wash your hands.

\section{- If you forget to take this drug:}

Never take two doses at once.

When you notice you have skipped one dose, take one dose immediately. If the next taking time is close, skip it and take the next dose at the next taking time.

\section{- If you take too many doses (overdose):}

There is a possibility of appearance of symptoms such as convulsion, drowsiness (become drifty with sleepiness), agitation, hyperponesis, abnormal behavior (behavior different from normal), digestion symptoms, mydriasis (glaring), fast pulse (thumping and dizziness), dry mouth (thirstiness), free-floating dizziness (dizziness and wobble), tremor (shaking of hands and feet), and increased blood pressure (dizziness, headache). If several of the above symptoms occur, immedi ately consult your physician.

\section{【What do you have to be careful about when taking this drug?】}

- Please ask for a thorough explanation of this drug until the patient (or the guardian of the patient or the caregivers fully understands the role of this drug and side effects

Figure 3 (Continued) 
of this drug in treating the disease. When a child uses this drug, the guardian or the similar person should understand the appropriate use of the drug and supervise the child.

- When this drug is used for a long time, efficacy of this drug is evaluated by setting a free period as necessary.

- When a child is using this drug, the patient may think of suicide or dying. The guardian or the caregivers should observe the changing mood of the patient, and if the change is observed, consult the physician.

- $\mathrm{AD} / \mathrm{HD}$ patients may often act aggressively and feel hostile. There are reports that patients act aggressively, feel hostile or symptoms get worse during the use of this drug. The family member should observe the change of the patient carefully and where you observe such changes, consult the physician.

- There are reports that this drug may cause psychotic symptoms such as hallucination or maniac symptoms. The family member should observe the change of the patient carefully and when you observe such changes, consult the physician.

- This drug may cause sleepiness or dizziness. Do not operate machines that may cause danger such as driving a car.

- Blood pressure and heart rate (pulse rate) are periodically checked during the use of this drug.

- There are some reports that this drug may inhibit weight gain or cause delay in growth when using this drug for a child. When such symptoms occur during the use of this drug, the physician may decrease the dose or stop the drug.

- Please consult your physician if you are pregnant or there is a possibility of pregnancy.

- Please avoid breastfeeding.

- If you are seeing other doctors or purchase other drugs at a pharmacy, please tell your physician or the pharmacist that you are taking this drug.

\section{What are the adverse reactions?}

We put down serious adverse reactions and their major subjective symptoms below that need to be paid special attention to. It is common that a few subjective symptoms of side effects appear at the same time described in each of the following serious side effects. If this happens, immediately consult your physician or pharmacist.

\begin{tabular}{|l|l|}
\hline \multicolumn{1}{|c|}{$\begin{array}{c}\text { Serious adverse } \\
\text { reactions }\end{array}$} & \multicolumn{1}{|c|}{ Major subjective symptoms } \\
\hline $\begin{array}{l}\text { Disorder of liver } \\
\text { function }\end{array}$ & Tiredness, nausea, vomiting, decreased appetite, itching \\
\hline Jaundice & Yellow eyes, yellow skin, dark urine \\
\hline Hepatic failure & $\begin{array}{l}\text { Nausea, vomiting, decreased appetite, hand shivering like a bird trying } \\
\text { to fly }\end{array}$ \\
\hline $\begin{array}{l}\text { Anaphylactic } \\
\text { syndrome }\end{array}$ & $\begin{array}{l}\text { Tiredness, wobbly, decreased consciousness, disorganized thinking, warm } \\
\text { sensation, swelling around eyes and lips, cracked voice, shortness of } \\
\text { breath, breathlessness, palpitation, hives, decreased judgment }\end{array}$ \\
\hline
\end{tabular}

The above subjective symptoms can be categorized by the body locations where side effects may appear as follows. If you notice such symptoms, please refer to the chart of serious side effects.

\begin{tabular}{|l|l|}
\hline \multicolumn{1}{|c|}{ Location of body } & \multicolumn{1}{c|}{ Subjective symptoms } \\
\hline Entire body & Tiredness, wobbly \\
\hline Head area & Decreased consciousness, disorganized thinking, decreased judgment \\
\hline Face & Warm sensation \\
\hline Eyes & Yellow eyes, swelling around eyes and lips \\
\hline Mouth \& throat & Nausea, vomiting, cracked voice, swelling around eyes and lips \\
\hline Chest area & Nausea, shortness of breath, breathlessness, palpitation \\
\hline Stomach area & Decreased appetite, nausea \\
\hline Hands and legs & Hand shivering like a bird trying to fly \\
\hline Skin & Itching, yellow skin, hives \\
\hline Urine & Dark urine \\
\hline
\end{tabular}

Figure 3 (Continued) 
【What is the shape of this drug?】

\begin{tabular}{|c|c|c|c|c|}
\hline $\begin{array}{c}\text { Brand } \\
\text { name }\end{array}$ & $\begin{array}{c}\text { Strattera } \\
\text { capsule 5mg }\end{array}$ & $\begin{array}{c}\text { Strattera } \\
\text { capsule 10mg }\end{array}$ & $\begin{array}{c}\text { Strattera } \\
\text { capsule 25mg }\end{array}$ & $\begin{array}{c}\text { Strattera capsule } \\
40 \mathrm{mg}\end{array}$ \\
\hline Shape & $\begin{array}{c}\text { No.3 hard } \\
\text { capsule }\end{array}$ & $\begin{array}{l}\text { No.3 hard } \\
\text { capsule }\end{array}$ & $\begin{array}{l}\text { No.3 hard } \\
\text { capsule }\end{array}$ & $\begin{array}{l}\text { No.3 } \\
\text { capsule }\end{array}$ \\
& Major axis & Major axis & Major axis & Major axis \\
& $\begin{array}{c}15.8 \mathrm{~mm} \\
\text { Diameter }\end{array}$ & $\begin{array}{c}15.8 \mathrm{~mm} \\
\text { Minor axis }\end{array}$ & $\begin{array}{c}\text { Minor axis } \\
\text { Minor axis }\end{array}$ & $\begin{array}{c}\text { Minor axis } \\
5.85 \mathrm{~mm}\end{array}$ \\
\hline Weight & $5.85 \mathrm{~mm}$ & $5.85 \mathrm{~mm}$ & $0.85 \mathrm{~mm}$ & $0.28 \mathrm{~g}$ \\
\hline ID code & Lilly 3226 & Lilly 3227 & Lilly 3228 & Lilly 3229 \\
\hline
\end{tabular}

【What are the ingredients of this drug?】

\begin{tabular}{|c|l|c|c|c|}
\hline $\begin{array}{c}\text { Brand } \\
\text { name }\end{array}$ & \multicolumn{1}{|c|}{$\begin{array}{c}\text { Strattera } \\
\text { capsule 5mg }\end{array}$} & $\begin{array}{c}\text { Strattera } \\
\text { capsule 10mg }\end{array}$ & $\begin{array}{c}\text { Strattera } \\
\text { capsule 25mg }\end{array}$ & $\begin{array}{c}\text { Strattera capsule } \\
40 \mathrm{mg}\end{array}$ \\
\hline $\begin{array}{c}\text { Active } \\
\text { ingredient }\end{array}$ & \multicolumn{3}{|c|}{ Atomoxetine hydrochloride (Atomoxetine) } \\
\hline Excipients & Partially pregelatinized starch, dimethylpolysiloxane (For internal use) \\
\cline { 2 - 5 } & $\begin{array}{l}\text { Capsule: Yellow } \\
\text { ferric oxide, } \\
\text { sodium lauryl } \\
\text { sulfate, gelatin }\end{array}$ & $\begin{array}{l}\text { Capsule: } \\
\text { Titanium oxide, } \\
\text { sodium lauryl } \\
\text { sulfate, gelatin }\end{array}$ & $\begin{array}{l}\text { Capsule: Food } \\
\text { blue No.2, } \\
\text { sodium lauryl } \\
\text { sulfate, gelatin }\end{array}$ & $\begin{array}{l}\text { Capsule: Food } \\
\text { blue No.2, } \\
\text { sodium lauryl } \\
\text { sulfate, gelatin }\end{array}$ \\
\hline
\end{tabular}

\title{
【Other information】
}

- How do you store this drug?

- Please store this drug in the room temperature $(1 \sim 30 \otimes)$ and avoid direct sunlight and humidity.

- Please keep out of reach of children

- What do you do with the unused drugs?

- Never give them to other people.

- If you have remaining drugs in hand, please consult your pharmacy or medical institutions.

\section{【Where do you ask about this drug ?】}

- For further questions such as symptoms, usage and side effects, please ask your physician or your pharmacist.

- For general information, please contact the following manufacturer.

\author{
Manufacturer \& distributing company: \\ Eli Lilly Japan K.K. (http://www.lilly.co.jp) \\ Drug information inquiry phone number \\ Lilly Answers \\ Telephone: 0120 -245-970 (Non-professional and patients' inquiry) \\ Hours: 08:45 17:30 (Except Saturdays, Sundays, national holidays and our \\ company's special holidays)
}

Figure 3 Current version of the Straterra Drug Guide for Patients in English.

with Bonferroni corrections. Finally, the interviewers conducted another short, semi-structured interview with each participant on their views and opinions of the drug guides.

\section{Analysis}

To measure the accessibility of the leaflets, we recorded the time that participants took to find the answer for each question and judged items that participants could find within two minutes as "accessible". According to EU guidelines, PLs are considered usable if $90 \%$ of people seeking requested information do in fact find it. This was used as a metric in the present study. For understanding, if participants were able to demonstrate an understanding such as rephrasing, they were marked as having "understood" the question. If a participant was unable to demonstrate such an understanding, they were marked as having "not understood". We performed 


\section{Drug Guide for Patients (Plan)}

Date of $1^{\text {st }}$ edition :

Date of the most recent revision :

\section{Strattera Capsules 5mg, 10mg, 25mg, 40mg}

\section{Generic name: Atomoxetine Hydrochloride}

\begin{tabular}{|c|c|c|c|c|}
\hline $\begin{array}{c}\text { Brand } \\
\text { name }\end{array}$ & $\begin{array}{c}\text { Strattera } \\
\text { Capsule 5mg }\end{array}$ & $\begin{array}{c}\text { Strattera } \\
\text { Capsule 10mg }\end{array}$ & $\begin{array}{c}\text { Strattera } \\
\text { Capsule 25mg }\end{array}$ & $\begin{array}{c}\text { Strattera } \\
\text { Capsule 40mg }\end{array}$ \\
\hline Shape & Lilly3226 & Lilly3227 & Lilly3228 & Lilly3229 \\
\hline ID code & Lill & & \\
\hline
\end{tabular}

\section{Contents}

1. What is this drug ? ....... p2

- What is it used for?

- What is its effect?

2. What is the most important thing about this drug? •.............. p2

3. What you need to know before taking this drug: $\cdots$ p2

- Do not take this drug, Precautions concerning use

- Clinical tests before you take this drug

4. What you need to pay attention to when taking this drug: . . . . . . p2

- Other medications and this drug

- Clinical tests while taking this drug - Old age
- Pregnancy or breast-feeding

- Children

- Driving and using machines

- Use with food, drink, and alcohol

- Information on inactive ingredients

5. How to use this drug $\cdots \cdots$ p2

- Dosage and administration

- If you forget to take this drug

- If you take too many doses

6. Adverse reactions $\cdots \cdots \cdot \mathrm{p} 2$

7. Others ….... p2

- How to store this drug

- Active ingredients

- Marketing authorization holder and manufacturer

\section{What is this drug?}

What is it used for?

Strattera is used for treating Attention Deficit/Hyper Activity Disorder (AD/HD) of a child and young people older than 6 years of age. $\mathrm{AD} / \mathrm{HD}$ is characterized by carelessness, hyperactivity and impulsiveness unmatched with age and development. It is a development disorder often observed among children and poses a problem for daily activity and study.

\section{What is its effect?}

Strattera functions to decrease impulsiveness and/or hyperactivity of $\mathrm{AD} / \mathrm{HD}$ patients by increasing attentiveness through increasing the amount of noradrenalin in the brain. Noradrenalin is a chemical substance naturally generated in the brain. This drug has been prescribed for improving the symptoms of $\mathrm{AD} / \mathrm{HD}$. There is no dependence property shown for this drug. It takes several weeks to fully improve the symptoms of this disease after taking Strattera.

\section{What is the most important thing about this drug?}

Please use this drug after listening to your physician and/or pharmacist and fully understanding the following.

- There are reports that this drug may have caused the thoughts of suicide, hallucination, aggressiveness and hostility in children and youngsters. Please observe the patient carefully while taking this drug and if such symptoms occur, immediately contact the physician or pharmacist.

- There are cases where weight increase is inhibited or physical growth is delayed at initiation of this drug among children. Please pay attention to the growth of the child and if the increase of height or weight is poor, the drug may be decreased or stopped by the instruction of the physician.

Figure 4 (Continued) 
3. What you need to know before taking this drug.

When using this drug in combination with other drugs.

Q Do not take this drug

- A person who has experienced allergy reaction from the ingredients contained in Strattera capsule in the past.

- A person taking selegiline hydrochloride (Brand name: FP tablet, which belongs to monoamine oxidase (MAO) inhibitors) to treat Parkinson's disease, or a person who has stopped taking it two weeks beforehand or earlier. (Such a person may confront serious side effects or lifethreatening danger if Strattera is taken in combination.)

- A person having a serious cardiovascular disorder.

- A person suffering from pheochromocytoma or who has suffered from pheochromocytoma in the past.

- A person suffering from angle-closure glaucoma (acute eye pain, headache, nausea and blurred vision).

$\bigcirc$ Precautions concerning use

- A person having liver and/or kidney disease.

- A person having convulsive seizure or who has had it before.

- A person having heart disease or a heart problem or having had one before.

- A person having high-blood pressure or having had it before.

- A person having cerebrovascular problem or having had it before.

- A person having low-blood pressure and who tends to become dizzy or faint.

- A person having a psychiatric problem.

- A person having difficulty starting urination.

Clinical tests before you take this drug

- Blood pressure and pulse rate are measured before and during Strattera use.

- EKG examination is conducted before taking this drug, in case there is a heart disease in the patient or the patient's family.

\section{What you need to pay attention to when taking this drug:}

Other medications and this drug.

Please do not take this drug in combination with the following drugs.

- A person taking monoamine oxidase (MAO) inhibitor or within two weeks of stopping this drug: This may cause serious side effects or life-threatening danger. (Please refer to No. 3 "What you need to know before taking this drug.")

- If you are taking or start taking the following drugs, please take special care. Do not fail to consult your physician or pharmacist. It is necessary to take special care when taking the following drugs.

- Drugs that change the amount of noradrenalin (Anti-depression drugs such as Venlafaxine and Mirtazapine or drugs to decrease hyperemia): Efficacy of the drug may become stronger.

- Drugs to increase blood pressure (dopamine hydrochloride, etc. to be used for cardiogenic shock): Blood pressure may be further increased.

- Drugs to inhibit drug-metabolizing enzyme (such as Paroxetine, etc. to be used for depression): Blood concentration of Strattera may increase.

- Drugs to affect beta-receptor (such as Salbutamol to be used for bronchial asthma): Drug efficacy to cardiovascular system may increase.

Clinical tests while taking this drug Blood pressure and pulse rate are measured before and during the usage of this drug.

Old age

There is no data for safety and efficacy of elderly people (65 years of age or older.)

$\bigcirc$ Pregnancy or breast-feeding

If you are pregnant (possibility of being so) or plan to be pregnant, please consult your physician. Do not use this durg during your pregnancy. It is not known that this drug may pass into breast milk. Therefore, avoid breastfeeding or stop this drug.

$\bigcirc$ Children

There are reports of inhibition of body weight or growth during the initial stage of using this drug among children. If you notice such symptoms during the use of this drug, please consult your physician. Safety and efficacy have not been investigated for babies with low birth weight, newborn babies, infants, and young children younger than the age of 6. (Please refer to No. 3 What you need to know before taking this drug.")

Figure 4 (Continued) 
Driving and using machines

After taking this drug, you may become dizzy or sleepy, so please do not drive a car. Please also do not operate a machine that may involve danger.

Use with food, drink, and alcohol

There is no particular information that you need pay attention to.

Information on inactive ingredients

There is no particular information.

$\bigcirc$ Dosage and administration

- Your physician will prescribe the dosage of this drug according to your symptoms. Please observe the dosage instruction of this drug given by your physician.

【Younger than 18 years old】

\begin{tabular}{|l|l|l|}
\hline Brand name & Strattera capsule $5 \mathrm{mg}, 10 \mathrm{mg}, 25 \mathrm{mg}, 40 \mathrm{mg}$ \\
\hline Frequency & \multicolumn{2}{|l|}{ Twice a day } \\
\hline One-day & Starting dose & Then after \\
\cline { 2 - 3 } dosage & $\begin{array}{l}0.5 \mathrm{mg} \text { per } 1 \mathrm{~kg} \text { of } \\
\text { body weight }\end{array}$ & $\begin{array}{l}0.8 \mathrm{mg} \text { per } 1 \mathrm{~kg} \text { of body weight and then increased to } \\
1.2 \mathrm{mg} \text { per body weight }\end{array}$ \\
\hline
\end{tabular}

- The dosage of this drug must be increased gradually over 1 week or more.

\section{【18 years or older】}

\begin{tabular}{|l|l|l|}
\hline Brand name & \multicolumn{2}{|l|}{ Strattera capsule $5 \mathrm{mg}, 10 \mathrm{mg}, 25 \mathrm{mg}, 40 \mathrm{mg}$} \\
\hline \multirow{2}{*}{$\begin{array}{l}\text { One-day } \\
\text { dosage }\end{array}$} & Once a day or twice a day \\
\cline { 2 - 3 } & $40 \mathrm{mg}$ & Then after \\
\hline
\end{tabular}

- When the dosage is increased to $80 \mathrm{mg}$ per day, it must be done gradually over 1 week or more. Additional dosage increase should be done gradually over two weeks or more.

\section{If you forget to take this drug}

When you notice skipping a dose, take one dose immediately. Never take two doses at one time. If the next taking time is close, skip it and take the next dose at the next taking time.

\section{If you take too many doses}

Immediately contact your physician or nearby emergency hospital and tell them how many capsules you have taken. Symptoms frequently reported are convulsion, tremor, dizziness, wobbling, gastrointestinal symptoms, dry mouth, drowsiness, fast pulse and abnormal behavior. If such symptoms appear, immediately stop the drug and visit your physician.

\section{Adverse Reactions}

Side effects may occur, but they do not necessarily occur in everybody. However when side effects happen, multiple symptoms may appear at the same time. When the symptoms occur, immediately consult your physician. Additionally if side effects not described here occur, please consult your physician or pharmacist.

\section{Serious side effects (Frequency of occurrence : not known.)}

When the following symptoms occur, stop using the drug and contact your physician or the hospital immediately. When the side effect is "shortness of breath," please see a physician by immediately calling an ambulance.

\begin{tabular}{|l|l|}
\hline \multicolumn{1}{|c|}{ Side effect } & \multicolumn{1}{c|}{ Major subjective symptoms } \\
\hline Anaphylactic & Entire body: Tiredness, wobbling \\
syndrome & Skin: Swelling around eyes and lips and hives \\
& Circulatory organ: Palpitation \\
& Respiratory system: Breathlessness, shortness of breath, cracked \\
& voice \\
& Nervous system: Feeling groggy \\
\hline
\end{tabular}

When the following symptoms occur, contact your physician immediately.

\begin{tabular}{|l|l|}
\hline \multicolumn{1}{|c|}{ Side effects } & \multicolumn{1}{c|}{ Major subjective symptoms } \\
\hline Liver disorder & Entire body: Tiredness, fever \\
[Disorder of liver & Skin: Rash, hives, itching, yellow skin \\
function, such as & Eye: White of eyes turns yellow \\
jaundice and & Digestive system: No appetite, nausea, vomiting, stomach ache \\
hepatic failure] & Others: Dark urine \\
\hline
\end{tabular}

Figure 4 (Continued) 
$\bigcirc$ Other side effects (Frequency of occurrence: up to 5 in 100 people)

\begin{tabular}{|l|l|}
\hline Location of body & \multicolumn{1}{|c|}{ Major subjective symptoms } \\
\hline Digestive system & Nausea, no appetite, stomach ache, vomiting, constipation, dry mouth \\
\hline Nervous system & $\begin{array}{l}\text { Headache, tend to fall asleep with drowsiness (existing conscious } \\
\text { disorder), dizziness with floating sensation }\end{array}$ \\
\hline Circulatory system & Palpitation \\
\hline Others & Weight loss \\
\hline
\end{tabular}

7. Others

How to store this drug

- Store the drug at the room temperature $\left(15 \sim 30^{\circ} \mathrm{C}\right)$ avoiding direct sunlight and humidity.

- Keep this drug out of reach of children. Never give this drug to other people.

- The unused drugs should not be thrown away in a wastebasket, but consult the pharmacy or medical institution for the method of disposal.

Active ingredients and excipients

Active ingredient: Atomoxetine hydrochloride (Each capsule contains atomoxetine hydrochloride equivalent to $10 \mathrm{mg}, 25 \mathrm{mg}$, and $40 \mathrm{mg}$ in amount)

Excipients: Pregelatinized starch, dimethyl polysiloxane, sodium lauryl sulfate, gelatin, yellow ferric oxide ( $5 \mathrm{mg}$ capsule), titanium oxide (10mg capsule), food blue No. 2 (25mg and 40mg capsule)

$\bigcirc$ Marketing authorization holder and manufacturer Eli Lilly Japan K.K. (http://www.lilly.co.jp), Telephone: 0120-245-970

Japan Eli Lilly drug information inquiry (Lilly Answers)

About the Drug Guides for Patients
"Drug Guides for Patients" are prepared for patients and their family members to
understand the prescription drug properly and to help detect serious adverse reactions at an
early stage.
Therefore, this leaflet explains the content of the package insert in an easier manner than
had been originally prepared for healthcare professionals, so that a user understands what
he/she should know when using this drug.
If you think it is a serious adverse reaction of the drug use, immediately consult your
physician or pharmacist.
If there is anything that you do not understand, there is a contact phone number at the
end of this leaflet. For further information, please visit "Website providing pharmaceutical
and medical device information," http://www.info.pmda.go.jp/ for the package leaflet
information for healthcare professionals.

Figure 4 Revised version of the Straterra Drug Guide for Patients in English.

Chi-squared test for the results of accessibility and understandability for DGPs.

We analyzed the results of the leaflet evaluation (with a 4-point scale) using $t$-test with Bonferroni corrections. Finally, we extracted and categorized participants' views of the leaflets in order to identify the good points and areas for improvement in the leaflets.

\section{Results}

The response rates for Mercazole and Strattera were both $100 \%(n=27 / 27$ and $15 / 15$, respectively), and the median ages of participants in these groups were 46 years (range: 15-74 years) and 45 years (range: $21-65$ years), respectively. All participants' characteristics are shown in Table 1.

\section{User testing of accessibility and understandability of DGPs}

The results for the investigations of whether participants were able to find and understand the information in the drug guides are shown in Tables 2 and 3.

Regarding the accessibility of the current version of the Mercazole Guide, $<90 \%$ of participants were able to find the requisite information for three questions $(1,5$, and 7$)$ and were able to understand seven questions $(1,3,5,7,9,10$, and 12). In contrast, in the revised version, the accessibility rates for all questions were above $90 \%$; however, understandability rates were $<90 \%$ for four questions $(1,3,7$, and 10$)$.

As noted above, Questions 8 and 12 were asked only for the revised version of the Strattera guide. For both versions, 
Box I Table of contents in the revised versions of the Drug Guide for Patients

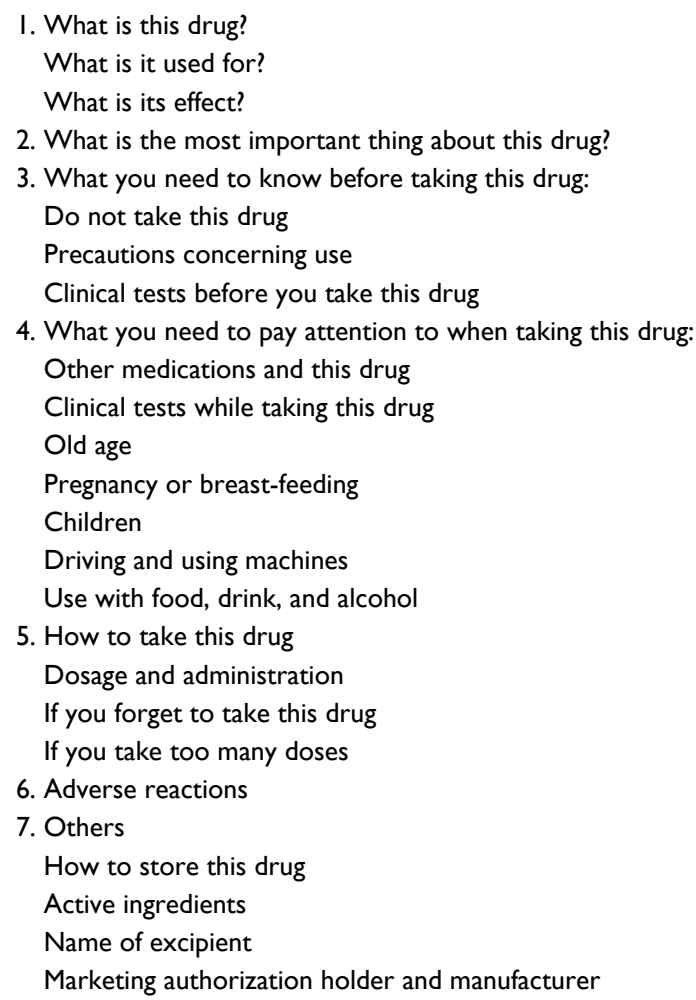

the accessibility rate was $<90 \%$ for only one question (9). In contrast, the understandability rates were $<90 \%$ for five questions $(3,5,7,9$, and 13$)$ in the current version and three questions $(2,8$, and 9$)$ in the revised version.

As a result, the revised version of Mercazole was superior to the current version in terms of both accessibility and understandability. For the Strattera guide, the revised version was better in terms of understandability. However, there was no statistically significant difference between the current and revised versions of both guides.
Tables 4 and 5 showed the average time it took to answer the questions. In the case of Mercazole, Question 5 showed a significant difference between the current and revised versions, while Questions 9 and 13 showed significant differences in Strattera.

\section{Comparison of the content and layout of DGPs}

The results of these analyses are shown in Table 6. We noted significant differences between the revised and current versions of both drug guides in terms of readability and layout and leaflet appearance (e.g., index, blank space, font size).

Participants' comments on each version are shown in Tables 7 and 8 . Several comments were made for both drugs. In the revised version of both drug guides, the "Table of Contents" was generally viewed as favorable, and they helped participants to understand the drug guides easily.

\section{Discussion}

Our aim was to demonstrate that the user testing method is effective for improving "Drug Guide for Patients" and would be useful for verifying other types of Japanese written materials. Our results clarified the differences in accessibility and understandability between the current and revised versions of the drug guides for Mercazole and Strattera. We used two different sample sizes to test the two drugs to help validate the statistical precision of this method among Japanese individuals. Their results are consistent with previously published articles. ${ }^{20-25}$

In 2013, we carried out a pilot study of user testing with ten participants, which identified areas for improvement with our testing method. ${ }^{26}$ Specifically, the interviewers' skills and attitudes toward participants were found to influence participants' answers. To avoid this bias, we have since standardized

Box 2 Questions of User Testing Items for the Mercazole Drug Guide for Patients

I. Imagine that you had some sort of abnormality in your liver. Would you be able to take Mercazole?

2. What would you do if you developed some cold-like symptoms while taking this medicine such as sore throat or feeling sluggish in general?

3. What kind of treatment is Mercazole used for?

4. Please tell me how to store this medicine.

5. Do tests need to be performed before using Mercazole? If so, what kinds of tests?

6. Let's say you took more Mercazole than the recommended dosage by mistake. Please mention one symptom that you think might occur in such a case.

7. Are there any severe side effects that can develop within 2 months of starting this medication?

8. You forgot to take a dose of Mercazole at some point. What should you do in this case?

9. What kinds of tests will you undergo, and when?

10. Imagine that you are already taking warfarin potassium for myocardial infarction. How should you approach taking Mercazole at this time?

II. Imagine that you are pregnant. What kinds of things do you think the doctor will caution you about?

12. Imagine that your 12-year-old child is taking Mercazole. At what dosage should his/her pediatric treatment begin?

13. After you have been taking Mercazole continuously for a while, you notice bleeding from your gums when you brush your teeth, and this continues for about a week. What should you do in this case? 
Box 3 Questions of User Testing Items for the Strattera Drug Guide for Patients

I. What kind of treatment is Strattera used for?

2. Imagine that your child has a serious heart disease. Would he/she be able to take Strattera?

3. Imagine that your child started treatment with Strattera but then suddenly developed dizziness, hives, and great difficulty breathing. What should you do?

4. How many times a day should it be taken?

5. At about what dosage should daily treatment begin?

6. Your child is already taking the Parkinson's drug selegiline hydrochloride (trade name: FP Tablets). What would the leaflet advise in this case?

7. Your child mistakenly broke open the Strattera capsule and the powder got into his eyes. What would the leaflet advise in this case?

8. In about how many people are side effects such as dizziness and palpitations reported? (revised draft only) ${ }^{\mathrm{a}}$

9. Your primary care physician is checking on your child's state of health. What kinds of tests will your child likely undergo?

10. Imagine that your child took more tablets than the usual dose. Please tell me the symptoms when too much of the medication is taken.

II. Your child had been taking Strattera as directed, but one day forgot to take it. What should you do?

12. Imaging that your child was already taking a drug called imipramine as treatment. What kind of effect do you think would result from taking it together with Strattera? (revised draft only) ${ }^{a}$

13. What kinds of things do you need to watch out for in particular when administering Strattera to children? What does the leaflet advise in such cases?

14. You have some Strattera left over because you forgot to take it several times. What should you do with the leftover medicine?

Notes: a Questions 8 and 12 are question items in the revised draft of the guide only, because the information they assess does not appear in the current guide.

Table I Participants' characteristics for the user tests of Drug Guide for Patients

\begin{tabular}{|c|c|c|c|c|c|}
\hline \multirow[t]{2}{*}{ Variable } & & \multicolumn{2}{|l|}{ Mercazole } & \multicolumn{2}{|l|}{ Strattera } \\
\hline & & $\begin{array}{l}\text { Revised version } \\
(n=27)\end{array}$ & $\begin{array}{l}\text { Current version } \\
(n=27)\end{array}$ & $\begin{array}{l}\text { Revised version } \\
(n=15)\end{array}$ & $\begin{array}{l}\text { Current version } \\
(n=15)\end{array}$ \\
\hline \multirow[t]{2}{*}{ Sex } & Male & 13 & 14 & 6 & 6 \\
\hline & Female & 14 & 13 & 9 & 9 \\
\hline \multirow[t]{7}{*}{ Age } & IOs & 2 & 3 & 0 & 0 \\
\hline & $20 \mathrm{~s}$ & 5 & 6 & 3 & 3 \\
\hline & $30 \mathrm{~s}$ & 5 & 6 & 3 & 3 \\
\hline & $40 s$ & 6 & 4 & 3 & 3 \\
\hline & $50 \mathrm{~s}$ & 4 & 3 & 3 & 3 \\
\hline & $60 s$ & 2 & 3 & 3 & 3 \\
\hline & Over 70s & 3 & 2 & 0 & 0 \\
\hline \multirow[t]{3}{*}{ Occupation } & White collar & 11 & 14 & 7 & 9 \\
\hline & Blue collar & 12 & 12 & 7 & 5 \\
\hline & Other & 4 & 1 & I & 1 \\
\hline Educational & Junior high school & 1 & 2 & 0 & 0 \\
\hline \multirow[t]{6}{*}{ level } & High school & 6 & 4 & 2 & 3 \\
\hline & Technical school & 7 & 8 & 5 & 2 \\
\hline & Two-year college & & & & \\
\hline & Undergraduate degree & 4 & 4 & 6 & 4 \\
\hline & Postgraduate degree & 2 & 3 & I & 4 \\
\hline & Currently in college & 7 & 6 & I & 2 \\
\hline
\end{tabular}

the interviewers' skills and attitudes through training. Furthermore, we recruited participants of a variety of literacy levels on this occasion. In the pilot study, participants appeared to feel nervous about taking part in user testing, even though we provided them with sufficient information about it. Thus, in the present study, we attempted to improve our user testing method by amending it based on our experiences in this pilot study.

We also improved the format for the revised version. We added a color photograph of the dosage form to the front page and a table of contents with various subindexes and accompa- nying page numbers. Furthermore, we highlighted important parts in red and boldface font and revised descriptions of the adverse reactions in plain Japanese. Hence, we amended the method and tested its efficacy in the present study.

Generally, the revised versions were superior to the current versions in terms of accessibility and understandability. More specifically, for the Strattera Guide, a significant difference was observed for questions regarding drug safety, which was not observed for Mercazole. A possible reason for the lack of difference in the latter guide is that the current 
Table 2 Accessibility and understandability of the Mercazole Drug Guide for Patients

\begin{tabular}{|c|c|c|c|c|c|c|c|c|}
\hline \multirow{3}{*}{$\begin{array}{l}\text { Question } \\
\text { number }\end{array}$} & \multicolumn{4}{|c|}{ Current version } & \multicolumn{4}{|c|}{ Revised version } \\
\hline & \multicolumn{2}{|c|}{$\begin{array}{l}\text { Able to find } \\
\text { information }(n=27)\end{array}$} & \multicolumn{2}{|c|}{$\begin{array}{l}\text { Able to understand } \\
\text { information }(n=27)\end{array}$} & \multicolumn{2}{|c|}{$\begin{array}{l}\text { Able to find } \\
\text { information }(n=27)\end{array}$} & \multicolumn{2}{|c|}{$\begin{array}{l}\text { Able to understand } \\
\text { information }(n=27)\end{array}$} \\
\hline & 24 & $88.9 \%$ & 19 & $70.4 \%$ & 26 & $96.3 \%$ & 21 & $77.8 \%$ \\
\hline 2 & 26 & $96.3 \%$ & 25 & $92.6 \%$ & 27 & $100.0 \%$ & 26 & $96.3 \%$ \\
\hline 3 & 27 & $100.0 \%$ & 17 & $63.0 \%$ & 27 & $100.0 \%$ & 23 & $85.2 \%$ \\
\hline 4 & 27 & $100.0 \%$ & 26 & $96.3 \%$ & 27 & $100.0 \%$ & 27 & $100.0 \%$ \\
\hline 5 & 22 & $81.5 \%$ & 16 & $59.3 \%$ & 25 & $92.6 \%$ & 25 & $92.6 \%$ \\
\hline 6 & 27 & $100.0 \%$ & 25 & $92.6 \%$ & 27 & $100.0 \%$ & 27 & $100.0 \%$ \\
\hline 7 & 24 & $88.9 \%$ & 16 & $59.3 \%$ & 27 & $100.0 \%$ & 24 & $88.9 \%$ \\
\hline 8 & 27 & $100.0 \%$ & 25 & $92.6 \%$ & 27 & $100.0 \%$ & 27 & $100.0 \%$ \\
\hline 9 & 26 & $96.3 \%$ & 22 & $81.5 \%$ & 26 & $96.3 \%$ & 26 & $96.3 \%$ \\
\hline 10 & 25 & $92.6 \%$ & 21 & $77.8 \%$ & 25 & $92.6 \%$ & 23 & $85.2 \%$ \\
\hline 11 & 27 & $100.0 \%$ & 26 & $96.3 \%$ & 27 & $100.0 \%$ & 26 & $96.3 \%$ \\
\hline 12 & 27 & $100.0 \%$ & 24 & $88.9 \%$ & 27 & $100.0 \%$ & 25 & $92.6 \%$ \\
\hline 13 & 27 & $100.0 \%$ & 26 & $96.3 \%$ & 27 & $100.0 \%$ & 27 & $100.0 \%$ \\
\hline
\end{tabular}

Table 3 Accessibility and understandability of the Strattera Drug Guide for Patients

\begin{tabular}{|c|c|c|c|c|c|c|c|c|}
\hline \multirow{3}{*}{$\begin{array}{l}\text { Question } \\
\text { number }\end{array}$} & \multicolumn{4}{|c|}{ Current version } & \multicolumn{4}{|c|}{ Revised version } \\
\hline & \multicolumn{2}{|c|}{$\begin{array}{l}\text { Able to find } \\
\text { information }(n=15)\end{array}$} & \multicolumn{2}{|c|}{$\begin{array}{l}\text { Able to understand } \\
\text { information }(n=15)\end{array}$} & \multicolumn{2}{|c|}{$\begin{array}{l}\text { Able to find } \\
\text { information }(n=15)\end{array}$} & \multicolumn{2}{|c|}{$\begin{array}{l}\text { Able to understand } \\
\text { information }(n=15)\end{array}$} \\
\hline & 15 & $100.0 \%$ & 14 & $93.3 \%$ & 15 & $100.0 \%$ & 15 & $100.0 \%$ \\
\hline 2 & 15 & $100.0 \%$ & 9 & $60.0 \%$ & 15 & $100.0 \%$ & 12 & $80.0 \%$ \\
\hline 3 & 15 & $100.0 \%$ & 11 & $73.3 \%$ & 15 & $100.0 \%$ & 14 & $93.3 \%$ \\
\hline 4 & 15 & $100.0 \%$ & 15 & $100.0 \%$ & 15 & $100.0 \%$ & 15 & $100.0 \%$ \\
\hline 5 & 15 & $100.0 \%$ & 13 & $86.7 \%$ & 15 & $100.0 \%$ & 15 & $100.0 \%$ \\
\hline 6 & 15 & $100.0 \%$ & 15 & $100.0 \%$ & 15 & $100.0 \%$ & 15 & $100.0 \%$ \\
\hline 7 & 15 & $100.0 \%$ & 13 & $86.7 \%$ & 15 & $100.0 \%$ & 14 & $93.3 \%$ \\
\hline 8 & - & - & - & - & 15 & $100.0 \%$ & 13 & $86.7 \%$ \\
\hline 9 & 11 & $73.3 \%$ & 10 & $66.7 \%$ & 13 & $86.7 \%$ & 13 & $86.7 \%$ \\
\hline 10 & 15 & $100.0 \%$ & 15 & $100.0 \%$ & 15 & $100.0 \%$ & 15 & $100.0 \%$ \\
\hline II & 15 & $100.0 \%$ & 15 & $100.0 \%$ & 15 & $100.0 \%$ & 15 & $100.0 \%$ \\
\hline 12 & - & - & - & - & 15 & $100.0 \%$ & 14 & $93.3 \%$ \\
\hline 13 & 14 & $93.3 \%$ & 10 & $66.7 \%$ & 15 & $100.0 \%$ & 14 & $93.3 \%$ \\
\hline 14 & 15 & $100.0 \%$ & 15 & $100.0 \%$ & 15 & $100.0 \%$ & 15 & $100.0 \%$ \\
\hline
\end{tabular}

Notes: '-' indicates there are no explanation for questions 8 \& 12 in the current version of the leaflet, therefore participants were not asked the questions.

Table 4 Average time to find the answer to the questions for the Mercazole Drug Guide for Patients

\begin{tabular}{llll}
\hline $\begin{array}{l}\text { Question } \\
\text { number }\end{array}$ & $\begin{array}{l}\text { Current version } \\
(\mathbf{n}=27) \text { seconds }\end{array}$ & $\begin{array}{c}\text { Revised version } \\
(\mathbf{n}=\mathbf{2 7}) \text { seconds }\end{array}$ & *P-value \\
\hline 1 & 46.2 & 46.7 & \\
2 & 42.1 & 28.3 & \\
3 & 21.1 & 11.5 & $<0.01$ \\
4 & 26.1 & 32 & \\
5 & 69.2 & 26.6 & \\
6 & 18.7 & 27.3 & \\
7 & 37.7 & 40.1 & \\
8 & 18.3 & 19 & \\
9 & 26.7 & 31.6 & \\
10 & 57.8 & 36.4 & \\
11 & 23.2 & 19.3 & \\
12 & 15.4 & 21.7 & \\
13 & 35.5 & 21 & \\
\hline
\end{tabular}

Notes: $* P$ value: $t$-tests with Bonferroni corrections.
Table 5 Average time to find the answer to the questions for the Straterra Drug Guide for Patients

\begin{tabular}{llll}
\hline $\begin{array}{l}\text { Question } \\
\text { number }\end{array}$ & $\begin{array}{l}\text { Current version } \\
(\mathbf{n}=15) \text { seconds }\end{array}$ & $\begin{array}{l}\text { Revised version } \\
(\mathbf{n}=15) \text { seconds }\end{array}$ & *P-value \\
\hline 1 & 10.1 & 7.8 & \\
2 & 34.7 & 21.8 & \\
3 & 51.1 & 19.9 & \\
4 & 21.1 & 7.5 & \\
5 & 41.2 & 28.1 & \\
6 & 53.7 & 34.1 & $<0.01$ \\
7 & 55 & 38.9 & \\
8 & - & 41.6 & \\
9 & 116.9 & 31.9 & $<0.01$ \\
10 & 36.7 & 9.8 & \\
11 & 14.6 & 7.3 & \\
12 & - & 27.1 & \\
13 & 124.6 & 34.6 & \\
14 & 11.6 & 18.4 & \\
\hline
\end{tabular}

Notes: *P-value: $t$-tests with Bonferroni corrections. ' - ' indicates there are no explanation for questions $8 \& 12$ in the current version of the leaflet, therefore participants were not asked the questions. 
Table 6 Evaluation of Drug Guide for Patients by the participants

\begin{tabular}{|c|c|c|c|c|c|c|}
\hline \multirow[t]{2}{*}{ Evaluation items } & \multicolumn{3}{|c|}{ Mercazole $(n=54)$} & \multicolumn{3}{|c|}{ Strattera $(n=30)$} \\
\hline & $\begin{array}{l}\text { Current } \\
\text { version }\end{array}$ & $\begin{array}{l}\text { Revised } \\
\text { version }\end{array}$ & $* \boldsymbol{P}$-value & $\begin{array}{l}\text { Current } \\
\text { version }\end{array}$ & $\begin{array}{l}\text { Revised } \\
\text { version }\end{array}$ & $* P$-value \\
\hline Amount of information and number of pages & 3 & 3.1 & & 2.9 & 3.1 & \\
\hline Readability & 2.6 & 3.2 & $<0.01$ & 2.5 & 3.2 & $<0.01$ \\
\hline Usefulness of information & 2.9 & 3.2 & $<0.01$ & 3 & 3.3 & \\
\hline Layout and leaflet appearance (e.g., index, blank space, font size) & 2.3 & 3.3 & $<0.01$ & 2.7 & 3.4 & $<0.01$ \\
\hline
\end{tabular}

Notes: $* P$ value: $t$-tests with Bonferroni corrections; $4=$ highly appropriate, $3=$ appropriate, $2=$ inappropriate, and $\mathrm{I}=$ highly inappropriate.

Table 7 Participants' comments on the Mercazole Drug Guide for Patients

\begin{tabular}{|c|c|c|c|c|}
\hline & Current version & $\mathbf{n}$ & Revised version & $\mathbf{n}$ \\
\hline $\begin{array}{l}\text { Amount of } \\
\text { information }\end{array}$ & No comment & 0 & “Many pages" & 3 \\
\hline \multirow[t]{2}{*}{ Readability } & $\begin{array}{l}\text { "The names of side effects for professionals is } \\
\text { unnecessary". }\end{array}$ & 7 & "Side effects are summarized nicely". & 3 \\
\hline & $\begin{array}{l}\text { "It is difficult to understand because jargon is frequently } \\
\text { used". }\end{array}$ & 15 & $\begin{array}{l}\text { "It is easier to understand because jargon is less frequently } \\
\text { used". }\end{array}$ & 6 \\
\hline $\begin{array}{l}\text { Usefulness of } \\
\text { information }\end{array}$ & "More informative" & 3 & $\begin{array}{l}\text { "It is easier to understand because professional } \\
\text { terminology is less frequently used". }\end{array}$ & 3 \\
\hline \multirow[t]{3}{*}{$\begin{array}{l}\text { Layout and } \\
\text { appearance }\end{array}$} & $\begin{array}{l}\text { "It is hard to find information because there is no table } \\
\text { of contents". }\end{array}$ & 8 & $\begin{array}{l}\text { "It is easier to understand because content and items have } \\
\text { been added". }\end{array}$ & 13 \\
\hline & $\begin{array}{l}\text { "Difficult to read due to too many letters written in black } \\
\text { and white". }\end{array}$ & 3 & $\begin{array}{l}\text { "There is a twist, such as colored characters and fonts to } \\
\text { the layout, so that it has become easier to read" }\end{array}$ & 27 \\
\hline & & & "Pictures are used effectively". & 22 \\
\hline
\end{tabular}

Table 8 Participants' comments for the Strattera Drug Guide for Patients

\begin{tabular}{|c|c|c|c|c|}
\hline & Current version & $\mathbf{n}$ & Revised version & $\mathbf{n}$ \\
\hline $\begin{array}{l}\text { Amount of } \\
\text { information }\end{array}$ & No comment & 0 & “Many pages” & 3 \\
\hline \multirow[t]{2}{*}{ Readability } & $\begin{array}{l}\text { "It is difficult to understand because jargon is } \\
\text { frequently used". }\end{array}$ & 8 & $\begin{array}{l}\text { "It is easier to understand because professional terminology } \\
\text { is less frequently used". }\end{array}$ & 8 \\
\hline & "Terminology for side effects is too difficult". & 8 & & \\
\hline $\begin{array}{l}\text { Usefulness of } \\
\text { information }\end{array}$ & No comment & 0 & "It is written from a user's viewpoint and is plain". & 3 \\
\hline \multirow[t]{3}{*}{$\begin{array}{l}\text { Layout and } \\
\text { appearance }\end{array}$} & $\begin{array}{l}\text { "Because there is no table of contents, it is hard to } \\
\text { look for information". }\end{array}$ & 2 & $\begin{array}{l}\text { "Because it has a table of contents and certain items, it is } \\
\text { easy to read". }\end{array}$ & 9 \\
\hline & "It is hard to read letters only in black and white". & $\mathrm{II}$ & $\begin{array}{l}\text { "There are markers such as colored letters and it is easy } \\
\text { to read". }\end{array}$ & 15 \\
\hline & & & "The font of the letters is good". & 2 \\
\hline
\end{tabular}

version of the Mercazole Guide has a greater volume of text than the revised version. A leaflet with more text-namely, one that contains more content-might make participants rely more on actively looking for the content. In contrast, a leaflet with less text would allow participants to easily read through and learn it before the testing began.

For the Mercazole Guide, questions on contraindication, clinical testing, and drug interaction (Questions 1, 5, and 10) were poorly understood in both versions, although the revised version was superior to the current version. For the Strattera Guide, questions on immediate action for side effects, clinical testing, and importance of notifying children (Questions 7, 9 , and 13) were poorly understood in both versions; again, however, the revised version showed superior understandability rates to the current version. A possible reason for these superior rates in the revised version is that lay language was used, in addition to adding a table of contents. However, the elderly had a tendency to take more time to answer all the questions, regardless of literacy level.

We improved the method and materials of user testing, but there are some limitations. One limitation was that we included only leaflets of two different types of drugs. We believe that it would be necessary to verify the drug guides of the other therapeutic groups of drugs for patients in the future. Another limitation concerns the participants; namely, their education levels were slightly higher than the general 
population group. In particular, about $35 \%$ of individuals in Japan have graduated university or graduate school; ${ }^{27}$ in contrast, in both of the groups, around 50\% had graduated from university or graduate school. This greater education level might have aided their understandability.

In the revised versions, participants tended to rate the readability and usefulness of the information rather high. Furthermore, there was a significant difference between the versions in readability for both drug guides, in favor of the revised version; this is likely because the revised versions contained more easy-to-understand words and expressions than did the current versions. In terms of design and layout, it is conceivable that the clarity of the revised versions was much greater. This was possibly due to the fact that the leaflet was organized with a table of contents and used colored lines for emphasis, which were missing in the current version.

In this study, we carried out user testing using printed DGPs. However, at present, these Guides are only accessible through the Web, and it is expected that increasingly more consumers will access them using smartphones in the future. Therefore, we would like to verify the adoption of user testing through electronic versions of DGPs in future research. We might also investigate their use for leaflets of different drug types.

\section{Conclusion}

This study employed user testing to compare different versions of DGPs. We showed that accessibility and understandability of the revised versions of the DGPs were superior to those of the current versions. Overall, the results indicated that user testing is a useful way of identifying the accessibility and understandability of such drug guides.

\section{Acknowledgments}

The study was approved by the Research Ethics Committee of Showa Pharmaceutical University, and supported by a Health and Labour Sciences Research Grant (H201 in fiscal years 2015-2018) from MHLW. The study sponsor (MHLW) did not influence the study design; collection, analysis, and interpretation of data; writing of the report; or the decision to submit the report.

\section{Disclosure}

The authors report no conflicts of interest in this work.

\section{References}

1. Koo M, Krass I, Aslani P. Consumer opinions on medicines information and factors affecting its use - an Australian experience. Int J Pharm Pract. 2002;10(2):107-114.
2. Raynor D, Dickinson D. Key principles to guide development of consumer medicine information - content analysis of information design texts. Ann Pharmacother. 2009;43(4):700-706.

3. Grime J, Blenkinsopp A, Raynor D, Pollock K, Knapp P. The role and value of written information for patients about individual medicines: a systematic review. Health Expect. 2007;10(3):286-298.

4. Kanmachi A, Okumura R. The prescription support by community pharmacists: the pharmaceutical cooperation by using Yakujo. Med Drug J. 2007;43(8):2071-2076.

5. Yamazaki K, Harada K, Arakawa M, Kurosu T, Ebihara A, Fujimura A. Benefits of providing information about drug therapy to patients. Jpn J Clin Pharmacol Ther. 1995;26(4):831-838.

6. Risk/Benefit Assessment of Drugs - Analysis and Response (RA-DAR) Council. Available from: http://www.rad-ar.or.jp/.. Accessed December $12,2016$.

7. The drug guides for patients' webpage in Japan. Available from: https:// www.pmda.go.jp/safety/info-services/drugs/items-information/guidefor-patients/0001.html. Accessed December 12, 2016.

8. Drug risk management plan in Japan. Available from: https://www. pmda.go.jp/safety/info-services/drugs/items-information/rmp/0002. html. Accessed December 12, 2016.

9. Yamamoto M, Doi H, Furukawa A. [Drug information for patients (package leaflets), and user testing in EU]. Yakugaku Zasshi. 2015;135(2): 277-284. Japanese.

10. Guideline on the Readability of the Labelling and Package Leaflet of Medicinal Products for Human Use. Revision 1. 2009. Available from: http://ec.europa.eu/health/files/eudralex/vol-2/c/2009_01_12_ readability_guideline_final_en.pdf. Accessed December 12, 2016.

11. Guideline on the Packaging Information of Medicinal Products for Human Use Authorised by the Union by European Commission in 2015. Available from: http://ec.europa.eu/health/files/eudralex/vol-2/201502_packaging.pdf. Accessed December 12, 2016.

12. Approved risk evaluation and mitigation strategies (REMS) in food and drug administration (FDA) in the US (United States). Available from http://www.accessdata.fda.gov/scripts/cder/rems/index.cfm. Accessed December 12, 2016

13. Pharmaceuticals and Medical Devices Agency (PMDA) website in Japan. Available from http://www.pmda.go.jp/english/index.html. Accessed December 12, 2016.

14. Yamamoto M, Matsuda T, Suka M, Furukawa A, Igarashi T, Hayashi M, Sugimori H. Research for the effective use of the medication guides for patients. Jpn J Soc Pharm. 2013;32(2):8-17.

15. Medicines and Healthcare products Regulatory Agency, Committee on Safety of Medicines. Always Read The Leaflet, Getting the Best Information with Every Medicine. Available from: https:/www.gov. uk/government/uploads/system/uploads/attachment_data/file/391090/ Always_Read_the_Leaflet__getting_the_best_information_with_ every_medicine.pdf. Accessed December 12, 2016.

16. Guideline on the Readability of the Labelling and Package Leaflet of Medicinal Products for Human Use. European Commission: Enterprise and Industry Directorate- General, Revision 1, 2009. Brussels.

17. Drug Guide for Patients of Mercazole. Available from: http://pmda.go.jp/ downfiles/ph/GUI/530471_1179050M1023_1_15G.pdf. Accessed December 12, 2016.

18. Drug Guide for Patients of Straterra. Available from http://pmda.go.jp/ downfiles/ph/GUI/530471_1179050M1023_1_15G.pdf. Accessed December 12, 2016.

19. Best Practice Guidance on Patient Information Leaflet by Medicines and Healthcare products Regulatory Agency (MHRA) in the United Kingdom. Available from: https://www.gov.uk/government/uploads/system/uploads/ attachment_data/file/328405/Best_practice_guidance_on_patient_information_leaflets.pdf. Accessed December 12, 2016.

20. Fuchs J, Hippius M. Inappropriate dosage instructions in package inserts. Patient Educ Couns. 2007;67(1-2):157-168.

21. Ahmed R, Raynor DK, McCaffery KJ, Aslani P. The design and usertesting of a question prompt list for attention-deficit/hyperactivity disorder. BMJ Open. 2014;16;4(12):e006585. 
23. McCormack L, Craig Lefebvre R, Bann C, Taylor O, Rausch P. Consumer understanding, preferences, and responses to different versions of drug safety messages in the United States: a randomized controlled trial. Drug Saf. 2016;39(2):171-184.

24. Raynor DK, Knapp P, Silcock J, Parkinson B, Feeney K. "User-testing” as a method for testing the fitness-for-purpose of written medicine information. Patient Educ Couns. 2011;83(3):404-410.

25. Knapp P, Raynor DK, Silcock J, Parkinson B. Can user testing of a clinical trial patient information sheet make it fit-for-purpose - a randomized controlled trial. BMC Med. 2011;9:89.
26. Yamamoto M. Pilot study for user test development of drug guided for patients. Fiscal year 2014 research report for grants in aid for scientific research by ministry of health, labour and welfare. 2015; 19-34.

27. National census in 2010 by Statistic Bureau, Ministry of Internal Affairs and Communications in Japan. Available from http:/www.stat. go.jp/data/kokusei/2010/users-g/wakatta.htm. Accessed December 12, 2016.

\section{Publish your work in this journal}

Drug, Healthcare and Patient Safety is an international, peer-reviewed open access journal exploring patient safety issues in the healthcare continuum from diagnostic and screening interventions through to treatment, drug therapy and surgery. The journal is characterized by the rapid reporting of reviews, original research, clinical, epidemiological and

\section{Dovepress}

post-marketing surveillance studies, risk management, health literacy and educational programs across all areas of healthcare delivery. The manuscript management system is completely online and includes a very quick and fair peer-review system. Visit http://www.dovepress.com/ testimonials.php to read real quotes from published authors.

Submit your manuscript here: https://www.dovepress.com/drug-healthcare-and-patient-safety-journal 